\title{
Hazard due to earthquake-induced rock falls: The use of remote sensing data and field mapping in the case of Skolis Mountain, NW Peloponnese
}

\author{
Litoseliti A. ${ }^{1}$, Koukouvelas I. ${ }^{1 *}$, Nikolakopoulos K. ${ }^{1}$ \\ ${ }^{1}$ Department of Geology, University of Patras, 265 00, Patras, Greece, iannis@upatras.gr

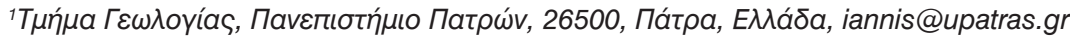 \\ ${ }^{*}$ Corresponding author: Prof I. K. Koukouvelas, University of Patras, Department of Geology, \\ 3126500 GR, e-mail: iannis@upatras.gr
}

\begin{abstract}
Inventory of pre-earthquake and earthquake triggered landslides is used to provide insight of the tectonic forcing in the development of the rock slopes of the Skolis Mountain, in the North Peloponnese. For the purposes of inventory of landslides we analyzed (C) Google Earth photographs based on drawing polygons and paths in order to create 'Keyhole Markup Language' or KML files. (c) Google Earth photographs analysis and surface mapping indicate that the Skolis Mountain is affected by long- term climatically and tectonically controlled rock falls and minor rock slides. The rock falls show a progressive inflation in surface area from 2007 to 2009. The post-earthquake surface area of the rock falls increased three times. In addition, there was a series of rock falls descending Skoli's slopes by free fall, bouncing, or rolling causing damages in the Santomerion village and blocking significant part of the dirt roads around it. These boulders are clustered in three areas across the western bluff of the mountain.
\end{abstract}

Key words: Landslides, earthquake-induces landslides, rock fall paths, NW Peloponnese

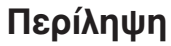

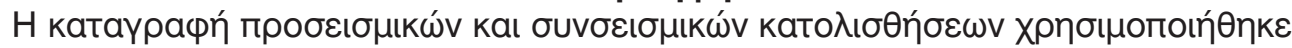

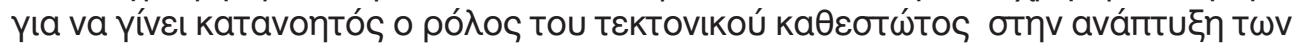

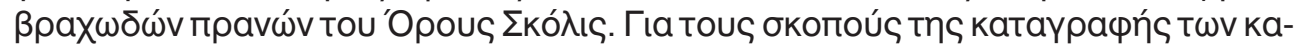

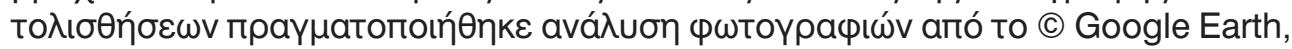

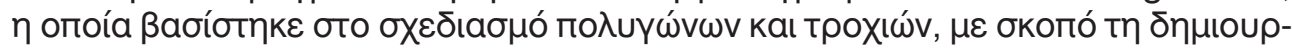

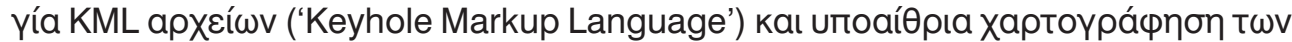

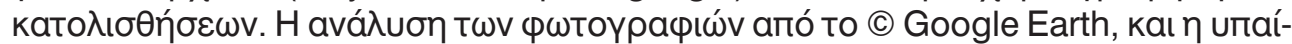

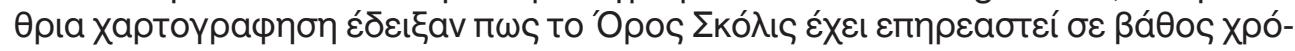

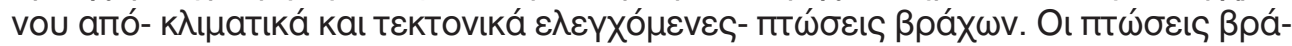

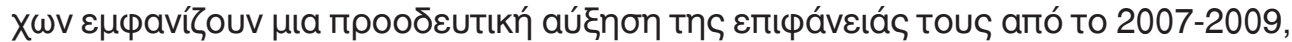

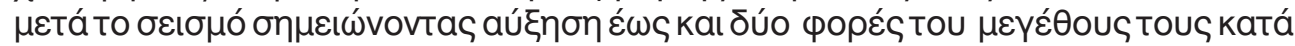
To 2007.

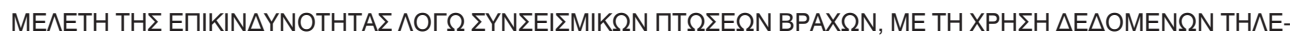

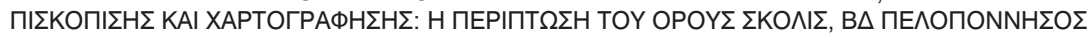

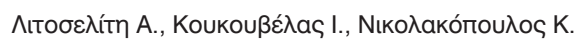




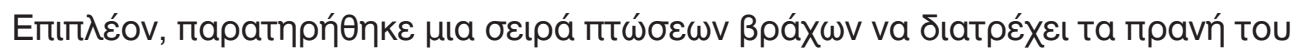

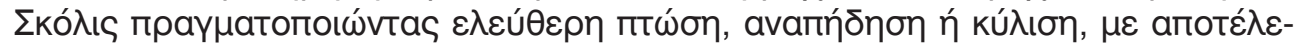

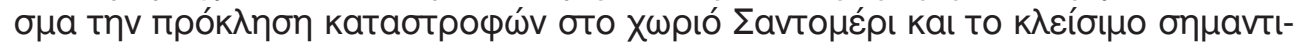

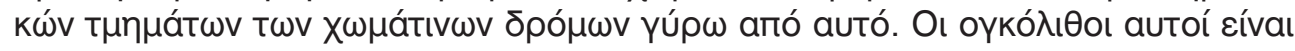

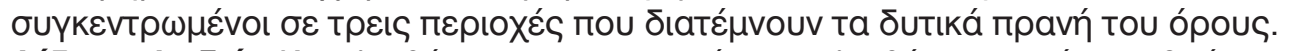

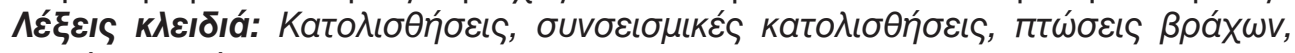

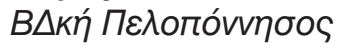

\section{Introduction}

Topography, lithology, tectonics and climatic conditions appear to control the distribution of both elastic stresses in rock masses and pore-water pressures, both of which eventually can produce slope instability (Crosta, 1998; Zezere et al., 1999). Earthquakes can also trigger landslides located on active faults or in the epicentral area (Keefer, 1984a; b; Koukouvelas et al., 1996; Bull et al., 1994; Tibaldi et al., 1995; Burbank and Anderson, 2001; Gallousi and Koukouvelas, 2007; Koukouvelas 2008). Mapping and detailed analysis of the landslides can be used for hazard assessments and estimates of rates of erosion and sediment discharge (Eisbacher and Clague, 1984; Keefer, 1984a). In addition, landslides in actively deforming areas often provides key data for earthquake hazard assessments and mechanism for delivering material from hillslopes into valley bottom occupied by rivers, lakes, gulfs or glaciers (Molin et al., 2004; Korup, 2005a,b; Gallousi and Koukouvelas, 2007).

Mass-movement occurs with a variety of mechanisms under virtually every environmental condition. In many countries around the world, landslides rank first among the natural hazard phenomena in terms of damage. Population growth, development and creation of new urban areas and construction engineering, have led to increased landslide phenomena in both natural and artificial slopes. The causes of these landslides depend on geological, tectonic, hydrogeological and climatic factors variously combined with human factors to induce the generation of failures. According to Keefer (1984a), earthquakes have long been recognized as major cause of landslides. Most moderate to large earthquakes trigger landslides, which can be either located on active faults or in the epicentral area (Keefer, 1984a; b; Koukouvelas et al., 1996; Gallousi and Koukouvelas, 2007). Earthquakes with magnitudes greater than 4.0 can trigger landslides on susceptible slopes, and earthquakes with magnitudes greater than 6.0 can generate widespread landsliding (Jibson and Keefer, 1993). Thus, landsliding at the time of earthquakes is a potential hazard in highly developed urban areas in seismically active regions. Seismically induced landslides occur synchronously with the seismic shock and direct failures, which take place some hours, or even days, after this.

Earthquakes in landslide-prone areas greatly increase the likelihood that landslides will occur due to ground shaking. Rock falls and topples are the most abundant earthquake-induced landslides, causing casualties and economic losses in many earthquakes (Keefer, 1984a). Rock falls are individual boulders or disrupted masses of rock that descend slopes by bounding, rolling, 
or free fall and they are especially dangerous because of their rapid movement and often lengthy distance of travel (Dorren, 2003). They can be caused by loosening of rocks or rocky formations, as a result of earthquake ground shaking. Rock falls originate on slopes steeper than $40^{\circ}$ and their continued occurrence forms talus slopes (Tinsley et al., 1985; Wilson and Keefer, 1985). In general, steeper slopes exhibit more frequently rock falls, as a consequence of gravity effects, while, the rock fall hazard extends to the foothills where usually populated areas are located.

On June 8th 2008, an earthquake of $\mathrm{Mw}=6.4$ struck northwestern Peloponnese. This event was the largest strikeslip earthquake occurred in western Greece during the past 30 years (Ganas et al., 2009; Koukouvelas et al., 2010). The earthquake toppled primarily old buildings and less reinforced houses and reinforced concrete buildings in the villages nearby its epicenter. The secondary effects that were caused by the $M w=6.4$ earthquake, were landslides, rock falls and rock slides, liquefaction phenomena and ground ruptures, near the epicentral area providing a quite good case history to evaluate the role of the earthquakes on triggering landslides (Kokkalas et al., 2008; Koukouvelas 2008; Pavlides et al., 2008; Koukouvelas et al., 2010; Papadopoulos et al., 2010). Seismic intensity assignments for this earthquakes based on the application of the Environmental Seismic Intensity scale (ESI 2007) and the European Macroseismic scale (EMS-98) suggest that a NE-SW trending elliptical area, including the Skolis Mountain, suffered by the event (see also Mavroulis et al., 2010).

Our study focuses to the case of Skolis Mountain, located entirely in the epicen- tral area, and landslides at Santomerion village where the most abundant secondary effects were recorded (Kokkalas et al., 2008; Koukouvelas et al., 2010; Papathanassiou 2012). The study of Skolis landslides support a subdivision of slope failures into two principal types: (a) primarily rock falls and (b) minor rock slides sensuVarnes (1978).

In this paper we investigate the distribution of rock falls during the Movri Mountain earthquake along the Skolis Mountain. Therefore, this paper is trying to address; (a) The role of the mountain morphology to the localization of the earthquake triggered and climatically controlled landslides. (b) The significance of the earthquake related landslides in modifying meteorologically controlled rock falls. (c) Hazard assessment due to sliding in the study area.

\section{Earthquakes and Landslides in Greece}

Innumerable landslides have been triggered worldwide by earthquakes during historic time and seismic activity have always been a main cause of landslides throughout the world (Yeats et al., 1997). Greece hosts since the antiquity a significant number of large earthquakes, as well as continuous background seismicity, due to its complex geological setting and the active tectonic deformation processes across a convergent plate boundary (Koukouvelas et al., 1996; Papadopoulos and Plessa, 2000; Kokkalas et al., 2006; Ambraseys, 2009). However, apart from the seismicity, extensive and frequent rainfall is a significant factor relative to landslide manifestation. It appears that the many and large landslides, which were or are still manifested in Greece, constitute geologically sensitive zones and are mainly found in Central and 
Western Greece (Koukis and Ziourkas, 1991; Kalantzi et al., 2010). This is supported by several parameters, such as "young" age and composition of geological formations, structural and geomorphological evolution. This results in the existence of numerous steep slopes, which in combination with erosion/weathering processes constituted landslides-prone areas. In particular, the common form of landslides occurring in Greece, are rock falls and rock slides and according to Koukis et al. (1996) rock falls represent 56 percent of the total failures for the rock formations. In addition, the hazard of rock falls increases in earthquake prone areas due to fact that earthquakes are a principal triggering factor (Marinos and Tsiambaos, 2002).

\section{Geological setting}

The study area is located in the northwestern Peloponnese, which occupies a part of the west-verging Alpine fold-andthrust belt in the External Hellenides (Fig. 1). Three geotectonic zones are defined in northwestern Peloponnese from the east to the west, the Pindos, GavrovoTropolitsa and Ionian zones, which commonly referred to as the isopic zones of the External Hellenides (i.e. Doutsos et al., 2006 and references therein). The External Hellenides are considered to have been part of a passive continental margin during the early Mesozoic Tethyan ocean opening (Robertson and Clift, 2000; Xypolias and Doutsos, 2000). The Gavrovo-Tripolitsa zone on the Skolis Mountain is consisted of late Cretaceous-Eocene shallow marine carbonates and late Eocene-Oligocene flysch in the surrounding area. Skolis Mountain is located at the tectonic boundary between the lonian and Gavrovo-Tripolitsa zones (Kamberis et al., 2000).
Northwestern Peloponnese and its surroundings lonian Islands are located at the most tectonically and seismically active region of Greece (Kokkalas et al., 2013 and references therein). More specifically, western Greece is characterized by ongoing subduction, comprising continent-continent collision in the north and ocean-continent subduction in the south, and mountain belt formation and consequent high seismicity (Underhill, 1989; Hatzfeld et al., 1988, 1995; Sachpazi et al., 2000; Kiratzi and Louvari, 2003; Doutsos et al., 2006; Serpetsidaki et al., 2009; Kokkalas et al. 2013). The northwest Peloponnese, located between the Corinth Rift and the Hellenic Arc, is considered as a transition zone characterized by dextral strike-slip faulting where the change between continent-continent and oceancontinent subduction occurs (Kokkalas et al., 2006; Koukouvelas et al., 2010). The historical and instrumental seismicity and geotectonic evolution of the NW Peloponnese and the Ionian Islands are in general well-known and widely reported (e.g. Hatzfeld et al., 1995; Sachpazi et al., 2000; Gallovic et al., 2009; Ganas et al., 2009; Papadopoulos et al., 2010; Royden and Papanikolaou, 2011; Vassilakis et al., 2011).

\section{The earthquake of June 8th 2008}

On the 8th of June 2008 an earthquake of magnitude $\mathrm{Mw}=6.4$ occurred in the area of Northwestern Peloponnese, western Greece (Fig. 1). The earthquake caused the death of two people, injuries, extensive damage to the surrounding area (along a $30-\mathrm{km}$-long by $20-\mathrm{km}$-wide area) and was reported to have been felt as far away as $350 \mathrm{~km}$ from the epicentral area. The main shock that occurred at 12:25:28 (GMT) on 8 June 2008, was located at latitude $37.98^{\circ} \mathrm{N}$ and longitude $21.51^{\circ} \mathrm{E}$ and was followed by a series of 
aftershocks with a maximum magnitude aftershock of 5.1 (Ganas et al., 2009; Papadopoulos et al., 2010). Focal mechanisms of the main shock as well as the lateral and vertical distributions of the af- tershocks imply a $\mathrm{N} 35^{\circ} \mathrm{E}$-striking blind dextral strike-slip fault (Ganas et al., 2009; Gallovic et al., 2009; Papadopoulos et al., 2010; Feng et al., 2010; Giannopoulos et al., 2013).

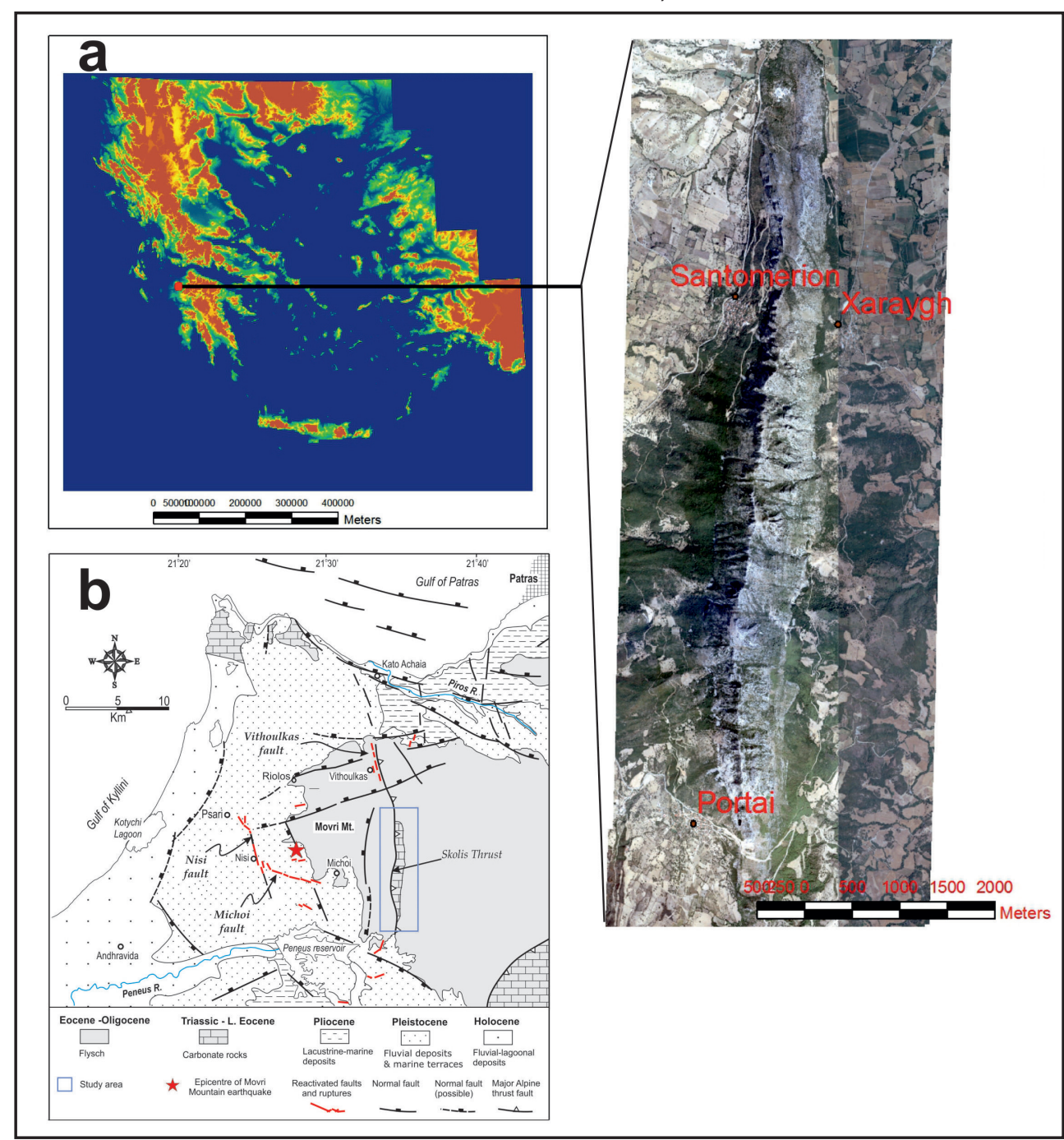

Fig. 1. (a) Location map and aerial orthophoto of the study area (Skolis Mountain) in NW Peloponnese, Greece. Orthophoto map has a spatial resolution of $25 \mathrm{~cm}$, and was extracted from (c) Google Earth. (b) Geological map of the NW Peloponnese showing lithology, active faulting and the surface ruptures that appeared during the Movri Mountain earthquake. The star indicates the epicenter of the earthquake. The geological map is modified from Koukouvelas et al., (2010).

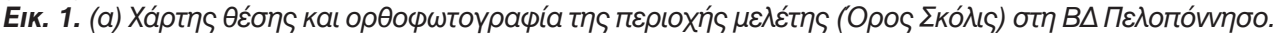

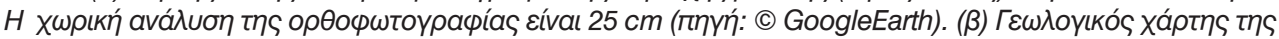

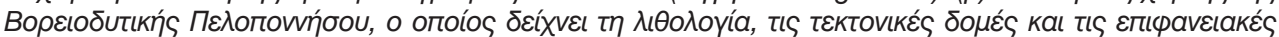

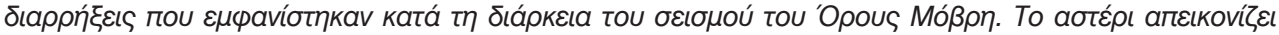

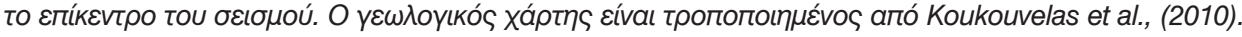


Regarding the focal depth, is about 20 $\mathrm{km}$, while recent estimates suggest that the Moho in northwest Peloponnese lies at a depth of about $27 \mathrm{~km}$, placing the focus of the main shock in the lower crust (Ganas et al., 2009; Papadopoulos et al., 2010).

For the epicentre location several calculations place the main event either west or east or south of Skolis Mountain. However, nowhere exist an almost $\mathrm{N}$ - or NE- trending high-angle fault on land to be interpreted as the candidate fault that hosted this earthquake (Koukouvelas et al., 2010).

Ground failures were widely observed within several kilometers of the fault, taking the form of seismic fractures, liquefaction phenomena, landslides and coastal subsidence (Zygouri et al., 2013 and references therein). These areas were Kato Achaia, Nisi and Pinios artificial lake, where liquefaction manifested as sand boils and flows of liquefied material, which probably consisted of clean sand or silty sand (Pavlides et al., 2008; Mavroulis et al., 2010). Seismic fractures were observed in Kato Achaia train station, where the rail lines were deformed or removed (see also Mavroulis et al. 2010; 2013). Overall failures occurred in the epicentral area of the 8 June 2008 earthquake depicted a complicated pattern (Koukouvelas et al., 2010). The earthquake triggered a significant number of landslides and rock falls particularly, in an area prone to slope failure, in a short distance from the epicenter.

\section{Materials and methods}

For the purposes of our study we used an extensive photographic archive of the mountain bluffs in combination with air-photos before and after the earthquake. Additional, helicopter photo shooting and surface mapping was used to map the Movri Mountain earthquake triggered landslides. Analytically our work is based not only on the mapping of the earthquake triggered landslides distribution but also on a campaign of structural mapping of discontinuities of the Skolis Mountain. In particular (c) Google Earth photographs analysis was based on drawing polygons and paths, in order to create $\mathrm{kml}$ files. KML, or 'Keyhole Markup Language', is an XML grammar and file format for modeling and storing geographic features such as points, lines, polygons, and models for display in (c) Google Earth. Google earth data has been used in many similar studies during the last years in order to produce landslide maps or landslide archives or the possibility of disseminating landslide information (e.g. Sato and Harp, 2009; Constanzo et al., 2012; Guzzeti et al., 2012; Schicker and Moon, 2012). Particullarly Peruccacci et al., (2012) compiled a catalogue of 442 rainfall events with landslides in three regions in Italy while the landslides were mapped using (c) Google Earth photographs. In a similar study Vennari et al, 2014 used Google (c) Earth photographs for the geographical allocation of the landslides. The horizontal Positional Accuracy of Google Earth's HighResolution Imagery and the positional accuracy of the (c) Google Earth terrain model were examined in several studies (i.e. Potere, 2008; Benker et al., 2011). Also in another study (Qiong et al., 2013) it was proved that the Google Earth imagery provides similar classification results compared to the original Quickbird satellite images. Hence, we marked the rock fall sites by drawing their contours as polygons and then we collected all the KML files to import 
them into ArcGis for our mapping purposes.

Rainfall data analysis used in our study was previously published by Karapanos (2009) suggesting that the period from April to September in the Skolis Mountain area is dry. In addition, most of the area has little vegetation, few trees and little soil and there are few surface streams flowing over the study area.

\section{The structure of the Skolis Mountain}

The Skolis Mountain is a $9 \mathrm{~km}$ long by $1.5 \mathrm{~km}$ wide anticline. The anticline is a fault related fold structure developed during the westward transportation of Mesozoic carbonates of the Tripolitza zone above the flysch of the Ionian zone. The main tectonic structure in the study area is represented by the overthrusting of Senonian-Eocene limestones of Gavrovo-Tripolitsa zone on the late Eocene-Oligocene Flysch of the Ionian zone that is called hereinafter as the Skolis Thrust. The Skolis Thrust appears in a large scale as a complex structure including planar and listric splays (Kamberis et al., 2005). However, at a mesoscopic scale the hanging wall of the Skolis Thrust appears as a moderately east dipping fault. The hanging wall block includes a two meters wide zone with intensive recrystallization and pressure solution cleavage. Fault rocks in the footwall block constitute a 15-m-wide zone of pulverized flysch including scarce flysch and limestone blocks as well. This fault is currently referred as inactive (Koukouvelas et al., 2010). Mesoscopic kinematic analysis of faults affecting the mountain in the study area indicates the existence of reverse, normal and strike-slip faults and joints (Kokkalas et al., 2003). Reverse faults constitute a conjugate system of faults trending nearly $\mathrm{N}-\mathrm{S}$ and dipping 700 eastwards or westwards. A second order cluster of NW-trending and NE-dipping faults showing oblique slip movements is registered. Normal faults include a system and a set of faults. The fault system constitutes a conjugate set of E-W to WNW-trending steeply dipping faults (average dip 70o). The fault set comprises N-S trending, west facing steeply dipping faults, probably related with the nappe movements to the west. Strike-slip faults are WNW-trending steeply dipping faults characterized by nearly horizontal slickensides. These tectonic structures in combination with the bedding of the limestone have caused intense deformation and fracturing of the rockmass, making it more susceptible to slope instability phenomena (fig. 2). The uppermost part of Santomerion village is covered by a large volume of rock fall debris.

The Skolis Mountain is not at a proximity with an active seismogenetic zone. Table 1 lists the main historic earthquakes felt in the study area. Landsliding events, including rock falls at Skolis Mountain have not been recorded during these earthquakes and no historic documents have been found about the occurrence of rock falls during the past earthquakes in this although, this possibility cannot be excluded.

\section{Landslides at Skolis Mountain}

The Skolis Mountain is characterized by steep slopes $(H: V=2: 1$ to $5: 1)$, especially at its western part and consists of limestones. The rock falls caused by the 8 June 2008 earthquake, was the result of the combination of the steeply inclined bedding and the very steep slopes of Skolis Mountain. Primarily its western slopes were affected by landslides. 


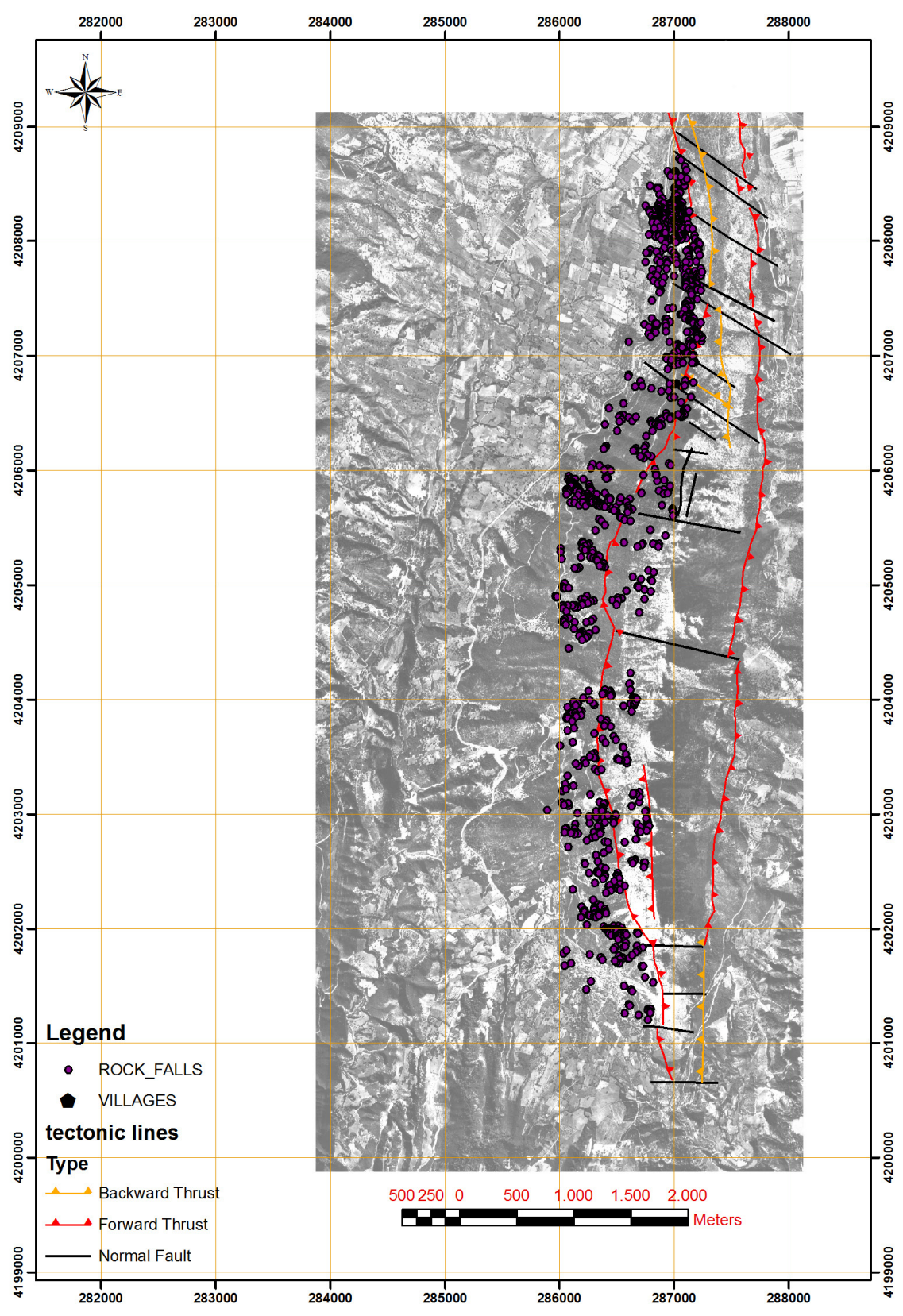

Fig. 2. Rock fall spatial distribution and tectonic features along the western slope of the Skolis Mountain. For legend see the lower left corner of the figure.

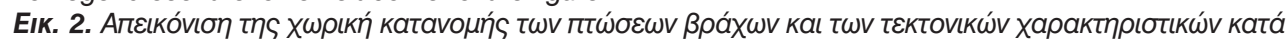

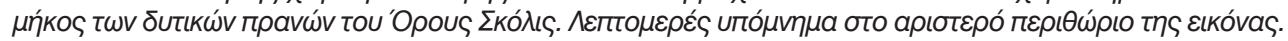




\begin{tabular}{|c|c|c|c|c|}
\hline Date & Origin Time & Latitude & Longitude & $\begin{array}{c}\text { Magnitude } \\
\text { (Mw) }\end{array}$ \\
\hline 20 May 2007 & $12: 49: 17.93$ & 37.820 & 21.209 & 4.4 \\
\hline 14 December 2007 & $05: 30: 59.30$ & 37.808 & 21.280 & 4.3 \\
\hline 8 June 2008 & $12: 25: 28.40$ & 37.945 & 21.544 & 6.8 \\
\hline 8 June 2008 & $12: 40: 53.90$ & 38.053 & 21.575 & 4.6 \\
\hline 8 June 2008 & $12: 43: 39.80$ & 38.101 & 21.584 & 5.0 \\
\hline 8 June 2008 & $12: 46: 52.90$ & 38.113 & 21.624 & 4.7 \\
\hline 8 June 2008 & $12: 55: 13.90$ & 38.095 & 21.629 & 4.7 \\
\hline 8 June 2008 & $13: 18: 53.80$ & 38.029 & 21.517 & 4.3 \\
\hline 8 June 2008 & $13: 20: 30.10$ & 38.034 & 21.565 & 4.1 \\
\hline 8 June 2008 & $13: 27: 49.80$ & 38.118 & 21.605 & 4.4 \\
\hline 8 June 2008 & $13: 31: 34.70$ & 38.014 & 21.554 & 4.2 \\
\hline 8 June 2008 & $13: 41: 48.70$ & 37.947 & 21.522 & 4.3 \\
\hline 8 June 2008 & $14: 01: 07.70$ & 38.067 & 21.575 & 4.4 \\
\hline 8 June 2008 & $16: 10: 06.60$ & 37.958 & 21.541 & 4.6 \\
\hline 8 June 2008 & $21: 10: 23.10$ & 37.981 & 21.573 & 4.4 \\
\hline 8 June 2008 & $21: 48: 30.40$ & 37.973 & 21.538 & 4.3 \\
\hline 9 June 2008 & $01: 32: 03.80$ & 38.042 & 21.579 & 4.6 \\
\hline 9 June 2008 & $13: 53: 21.70$ & 38.028 & 21.540 & 4.5 \\
\hline 9 June 2008 & $16: 18: 40.90$ & 38.042 & 21.575 & 4.3 \\
\hline 11 June 2008 & $02: 44: 00.80$ & 38.041 & 21.569 & 4.2 \\
\hline 12 June 2008 & $03: 15: 34.70$ & 37.974 & 21.650 & 4.4 \\
\hline 12 June 2008 & $12: 49: 06.30$ & 38.044 & 21.536 & 4.3 \\
\hline 12 June 2008 & $20: 36: 58.60$ & 38.016 & 21.554 & 4.1 \\
\hline 18 June 2008 & $17: 57: 26.30$ & 38.076 & 21.597 & 4.2 \\
\hline 24 June 2008 & $18: 14: 53.50$ & 38.136 & 21.681 & 4.1 \\
\hline 27 June 2008 & $05: 18: 55.50$ & 38.007 & 21.521 & 4.7 \\
\hline 5 July 2008 & $10: 34: 08.50$ & 38.041 & 21.548 & 4.8 \\
\hline 13 July 2008 & $16: 25: 10.70$ & 38.138 & 21.615 & 4.2 \\
\hline 20 August 2008 & $17: 26: 35.40$ & 37.850 & 21.343 & 4.3 \\
\hline 10 January 2009 & $22: 26: 23.80$ & 37.995 & 21.575 & 4.3 \\
\hline & & & & \\
\hline 1. The & & \\
\hline
\end{tabular}

Tabl. 1. The largest earthquakes of magnitude (Mw) greater than 4.0 in the study area, for the period 2007 to 2009 (for data see www.gein.noa.gr).

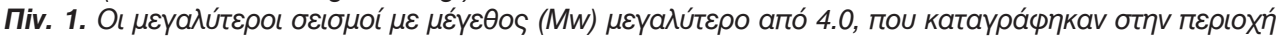

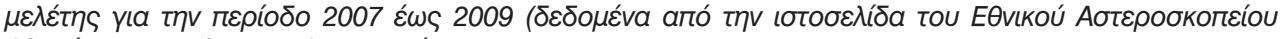

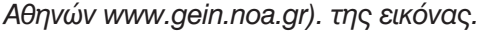


The toppling of large diameter detached limestone blocks accompanied by rock falls, affected the village Santomerion $\left(21.57275^{\circ}, 37.98848^{\circ}\right)$, damaging properties and the road network nearby the village after the earthquake. Smaller scale rock falls occurred at Portai and Xaravgi villages, at the southern and eastern foothills of Skolis Mountain respectively and also, along the road from Portai to Valmi village (Fig. 2).

The height of steep slopes across the Skolis Mountain exceeds $100 \mathrm{~m}$ for the case of Santomeri, whereas in the case of Portai, the height of the overhanging slopes is in the order of $50-80$ $\mathrm{m}$. Overall the steepness of the slopes is reduced towards the north end of the mountain.

The uppermost part of Santomerion village is covered by a large volume of rock fall debris. Our field- and aerial-photo mapping results indicate that the earthquake reactivated approximately 69 and triggered 15 new rock falls during the June 8th 2008 earthquake. In addition we mapped 990 isolated boulders dispersed on the western bluff of the mountain.

\subsection{Pre-earthquake landslides}

Mapping of the western slope of the Skolis Mountain during the 2007 indicates that the study area comprises a widespread landslide terrain. Scree accumulations are deposited where the steeply inclined to vertical carbonate rock walls contact to the flysch successions in the foothill.

They consist of fragments of rocks ranging extremely in size, which form high-gradient slopes with a sorting by size, showing the coarsest boulders toward the base of the slope as is expected on a talus slope in mountain ar- eas. At some location across the western bluff of the Skolis Mountain the deposits on the talus slope have an indurated crust made of well cemented carbonate breccias. Slopes are scarcely vegetated, and in wide areas vegetation is absent or consists only of shrubs.

Rock fall observed on the 2007 Quickbird satellite images (@ Google Earth). They are derived from fractured and faulted carbonate rocks that have been triggered by climatic forcing since historic earthquake activity was not in close proximity to the Skolis Mountain, during the past decades. The stability of the preexisting rock falls is estimated by detailed mapping of the pre-earthquake rock falls boundaries on satellite images, using the $\mathrm{kml}$ files (Figs 3 and 4).

The geometric distribution of all pre-existing rock falls was surveyed and plotted, in order to estimate the role of the earthquake on the slope stability either on the shape of the rock falls or in the length of their channels. The results indicate three geometric types of rock falls:

(a) Elongated rock fall channels (narrow channels) showing an I- to J-shape, which are located primarily within the limestones. Length of the I-shaped paths varies between 17 and $270 \mathrm{~m}$., while the length of the $\mathrm{J}$-shaped paths varies between 77 and $380 \mathrm{~m}$. This type includes small carbonate rocks and boulders, tumbling down the slopes.

(b) Fan shaped taluses characterized by minor or absent rock fall path deposited where the steeply inclined to vertical carbonate rock walls connect to the flysch successions in the foothill. From plan view, they show the typical features of a rock fall talus. This type is less frequent. 

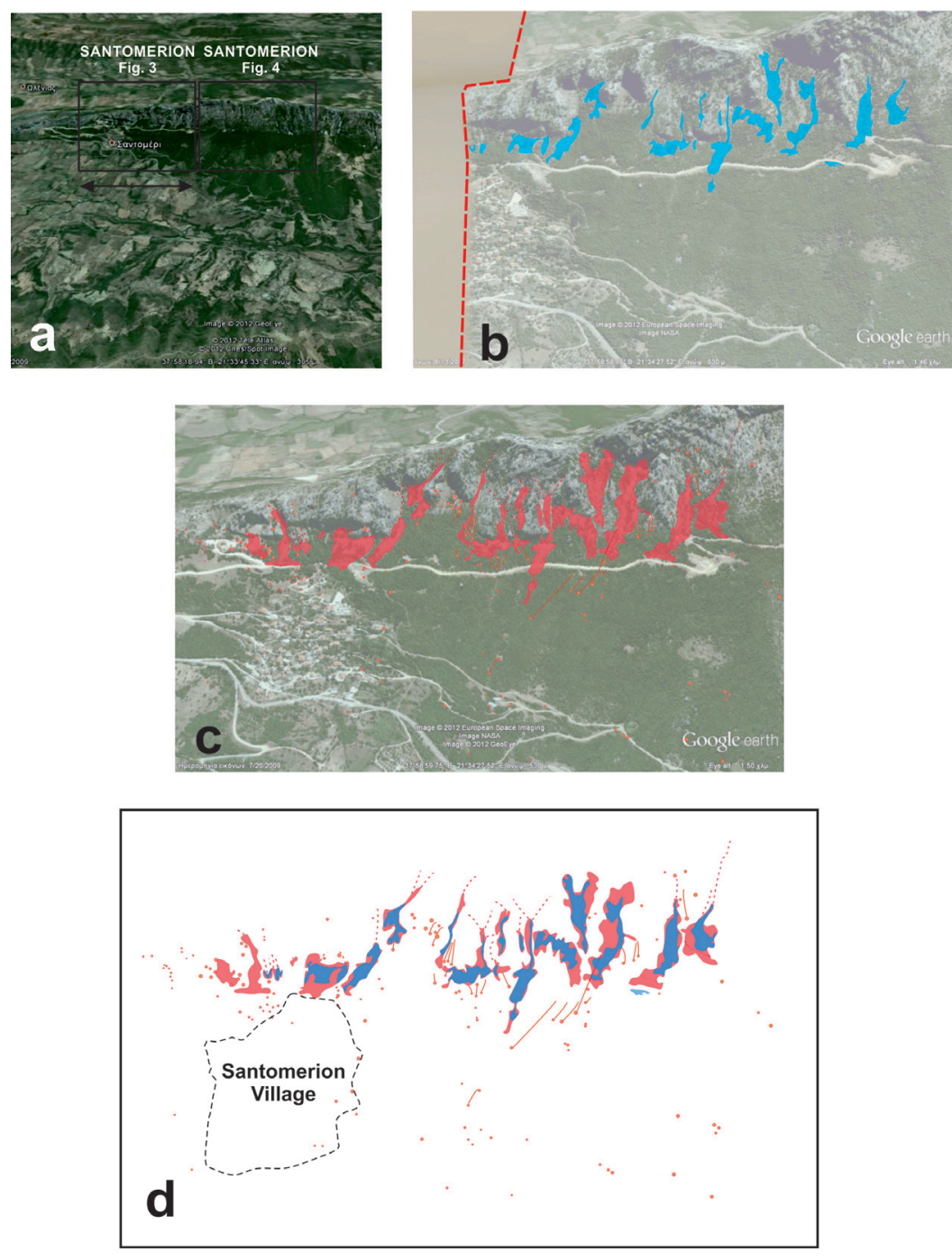

Fig. 3. Temporal evolution of the landslides of Santomerion village for the period 2007-2009. (a) Aerialphoto showing the analyzed area around Santomerion villagein figure 3, aerialphoto was extracted from (c) Google Earth. (b) Distribution of rock falls, before the earthquake, indicated by the blue areas; the bold red dashed line defines the area where the aerialphoto has low resolution. (c) Distribution of rock falls after the earthquake; red areas correspond to rock fall accumulation zones, the orange dots correspond to isolated blocks and the red lines to their trajectories. (d) Overlapping of pre-earthquake and post-earthquake rock falls around the Santomerion village.

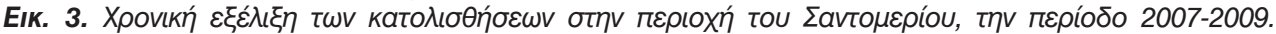

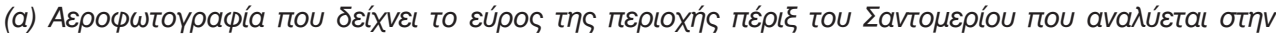

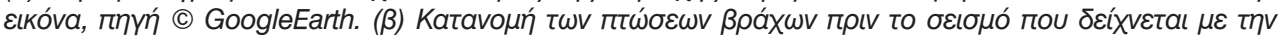

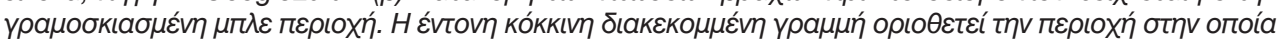

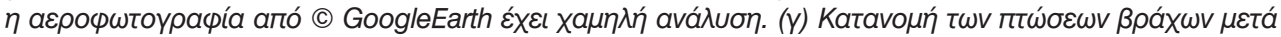

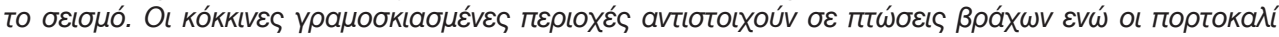

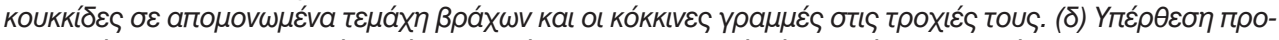

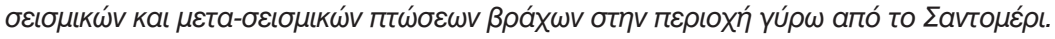



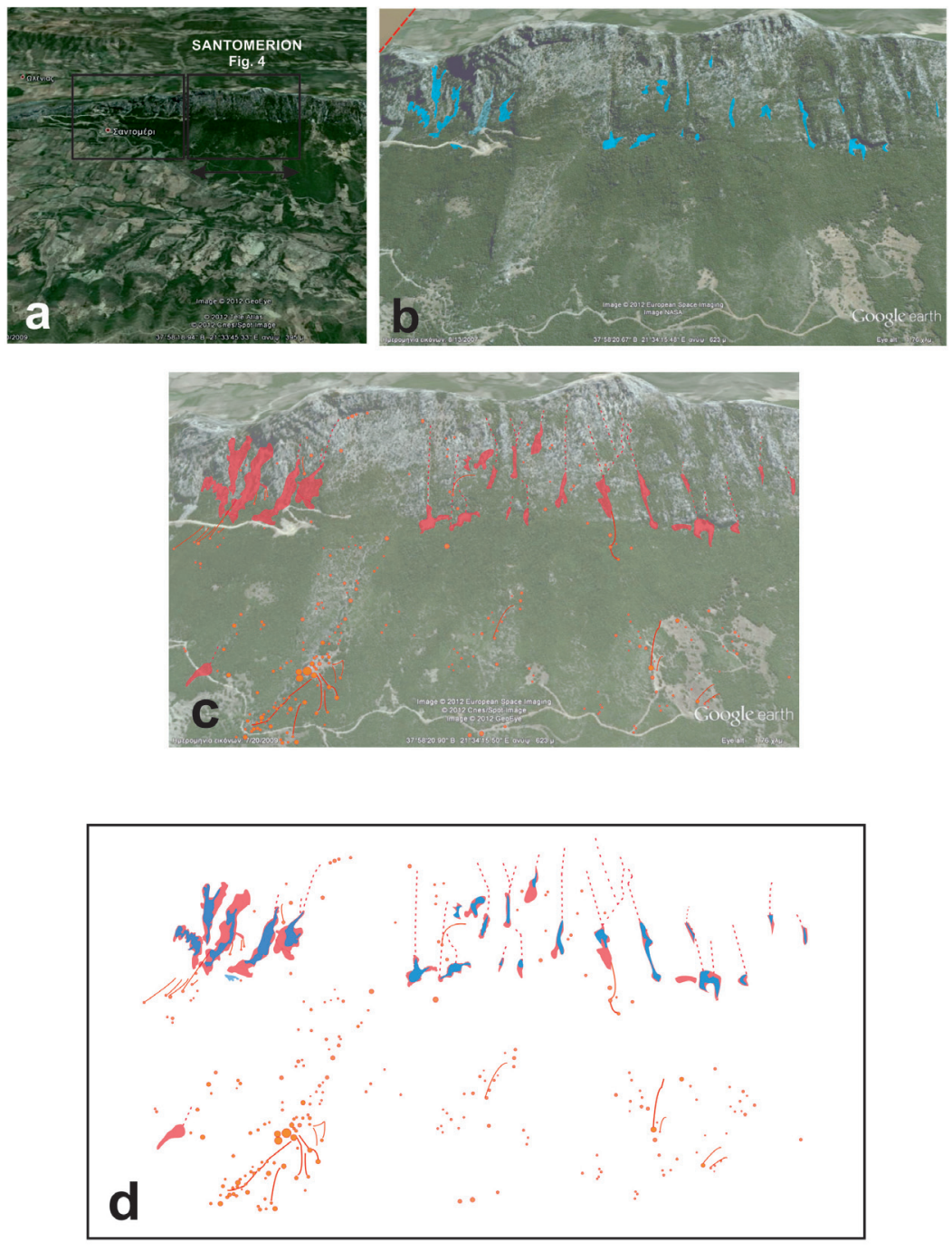

Fig. 4. Temporal evolution of the landslides to the south of Santomerion village for the period 2007-2009. (a) Aerialphoto showing the analyzed area south of Santomerion village in figure 4, aerialphoto was extracted from (c) Google Earth. (b) Distribution of rock falls, before the earthquake, indicated by the blue areas; the bold red dashed line defines the area where the aerialphoto has low resolution. (c) Distribution of rock falls after the earthquake; red areas correspond to rock fall accumulation zones, the orange dots correspond to isolated blocks and the red lines to their trajectories. (d) Overlapping of pre-earthquake and post-earthquake rock falls around the Santomerion village.

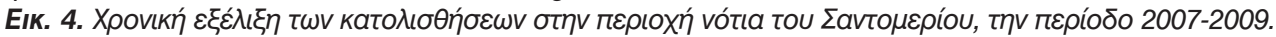

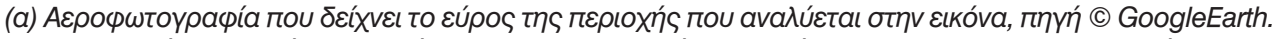

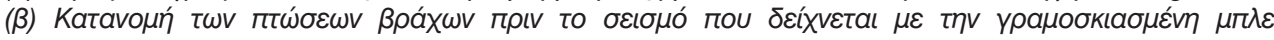

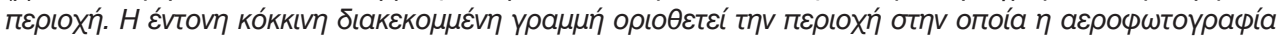

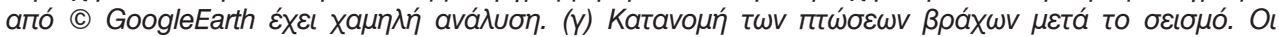

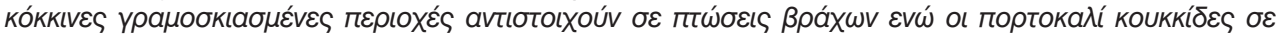

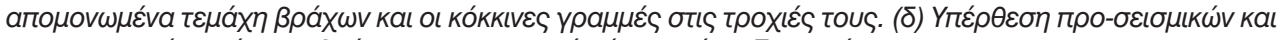

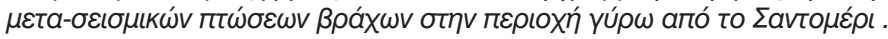


(c) Complex rock falls; they exhibit characteristics of a well developed rock fall path which change their initial characteristics while moving downslope, into the talus slope and evolved upslope, into an I- or J- shaped feeder zone. These rock falls consist of high concentrations in rocks and boulders. They consist of fragments of rocks ranging extremely in size from highgradient slopes with a sorting by size, showing the coarsest boulders toward the base of the slope as is expected on a talus slope in mountain areas.

\subsection{Post-earthquake rock falls}

After the June 8th 2008 earthquake, we performed a field reconnaissance of 84 rock fall sites, which were re-examined using aerial photos, for evidence of active movements. The reactivation of rock falls during the 2008 Movri earthquake provided a unique opportunity to evaluate the seismic stability of pre-existing rock falls. It should be noted that the reactivated rock falls not only occurred within preexisting rock fall masses, but also they have been fully mobilized by significantly increasing their size (Figs 3 and 4). Furthermore, the reactivation occurred within preexisting rock fall masses affecting the whole landslide body, as a result of the earthquake ground shaking. The examination and detailed mapping of the earthquake-triggered rock falls, after the Movri Mountain earthquake, showed that $84,5 \%$ of the 2007 rock falls are reactivated and $14.3 \%$ are newly formed (Fig. 5).

\section{Landslide Classification}

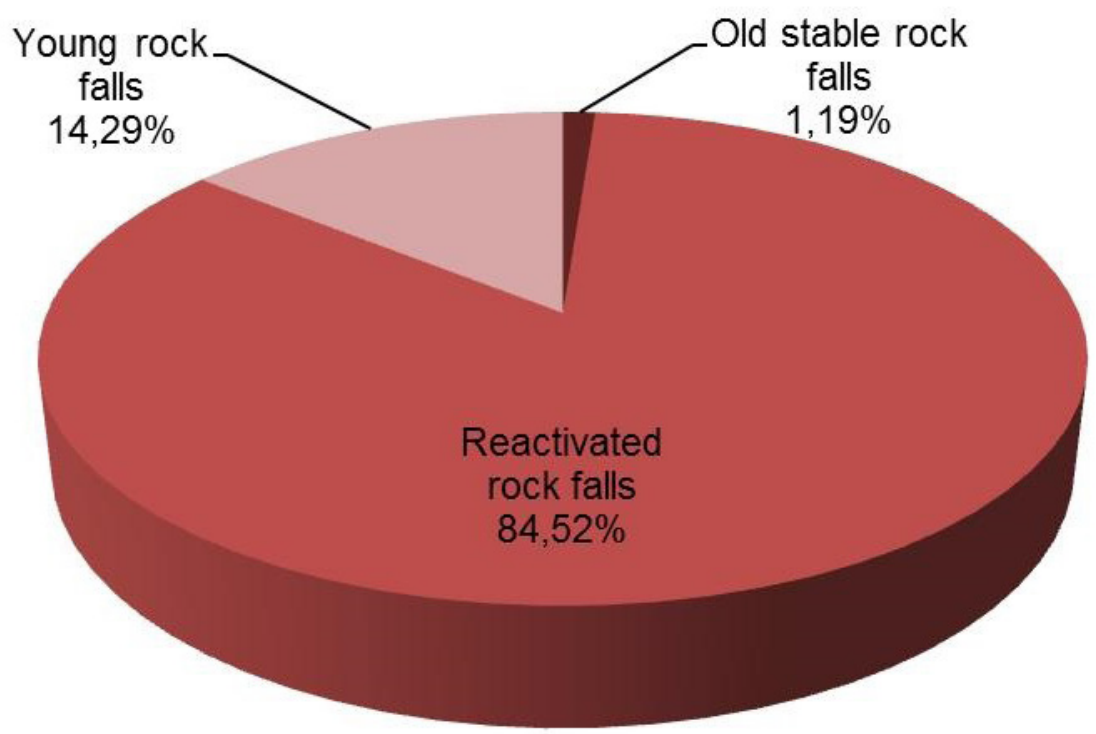

Fig. 5. Pie chart that indicates post-earthquake landslide classification resulting from field mapping on Skolis Mountain.

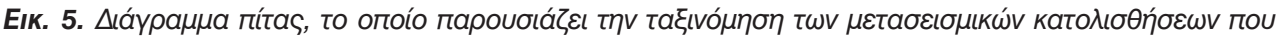

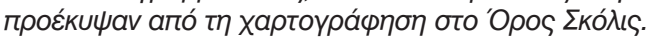


Apart from the main inflation occurred in the deposition area of the rock fall mass, a retrograde growth of the rock fall path took place, affecting almost all rock falls. Length of the I-shaped paths after the earthquake varies between 40 and $270 \mathrm{~m}$. Length of the $\mathrm{J}$-shaped paths after the earthquake varies between 160 and $380 \mathrm{~m}$. These data indicate that the length of the smaller of I-shape paths has increased from 17 to $40 \mathrm{~m}$ and $\mathrm{J}$-shaped paths from 77 to $160 \mathrm{~m}$. It is remarkable that the shape of many rock fall paths has changed from $\mathrm{I}$ - to $\mathrm{J}$ - as a result of the earthquake.

\subsection{Isolated rock falls}

Extensive rock falls occurred on the calcareous bedrock slopes of Skolis Mountain being the most impressive secondary effect of the Movri Mountain earthquake since boulders dispersed through the entire western bluff of the Skolis Mountain (Fig. 6). The three most important modes of motion are free fall through the air, bouncing on the slope surface and rolling over the slope surface (Dorren, 2003). In the case of free fall, failures mostly occur on vertically inclined carbonate rockwalls, such as is the case for the overhanging slopes east of Santomerion village, while the bounce requires less steep slopes. In regard to the release points we identified several outcrops with height of detachment ranging between 600-970 m (Fig. 8). Rock falls as isolated boulders were mapped just after the earthquake: (a) Boulders, which are broken down into smaller pieces, after their detachment from the Skolis bluffs. The latter is identified at least at 10 outcrops, where fresh rock faces are appeared in the bluff above Santomerion. (b) Individual boulders rolling down the slopes, indicating in that way a trajectory, from their source until they come to a standstill (Fig. 8b). The rolling mode happened on where gentle slopes are denoted by tracks through crushed bushes. Therefore, trajectories consist of linear vegetation uprooting, indicating the maximum run-out distance of boulders (Fig. 8c).

\begin{tabular}{|c|c|}
\hline \multirow{2}{*}{ Rock Fall Zonation and its Main Characteristics } \\
\hline \multirow{4}{*}{ Rock fall source area } & High relief \\
\cline { 2 - 2 } & Related with fault zones, or the fold crest \\
\cline { 2 - 2 } Talus slope & Dense pattern of discontinuities \\
\cline { 2 - 2 } & Rock fall detachment areas \\
\hline \multirow{4}{*}{ Rock fall accumulation area } & High density of discontinuities \\
\cline { 2 - 2 } & Transition from high to medium slope gradient \\
\cline { 2 - 2 } & Scarce Vegetation \\
\hline \multirow{4}{*}{$\begin{array}{c}\text { Run-out zones of rock fall events medium to } \\
\text { low relief }\end{array}$} \\
\cline { 2 - 2 } & Bushes and few trees \\
\cline { 2 - 2 } & Proximity to residential areas \\
\hline
\end{tabular}

Tabl. 2. . Main characteristics of the rock fall distribution, which form a hazard zonation on the slopes of Skolis Mountain.

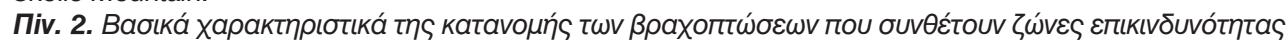

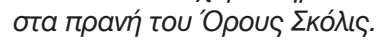




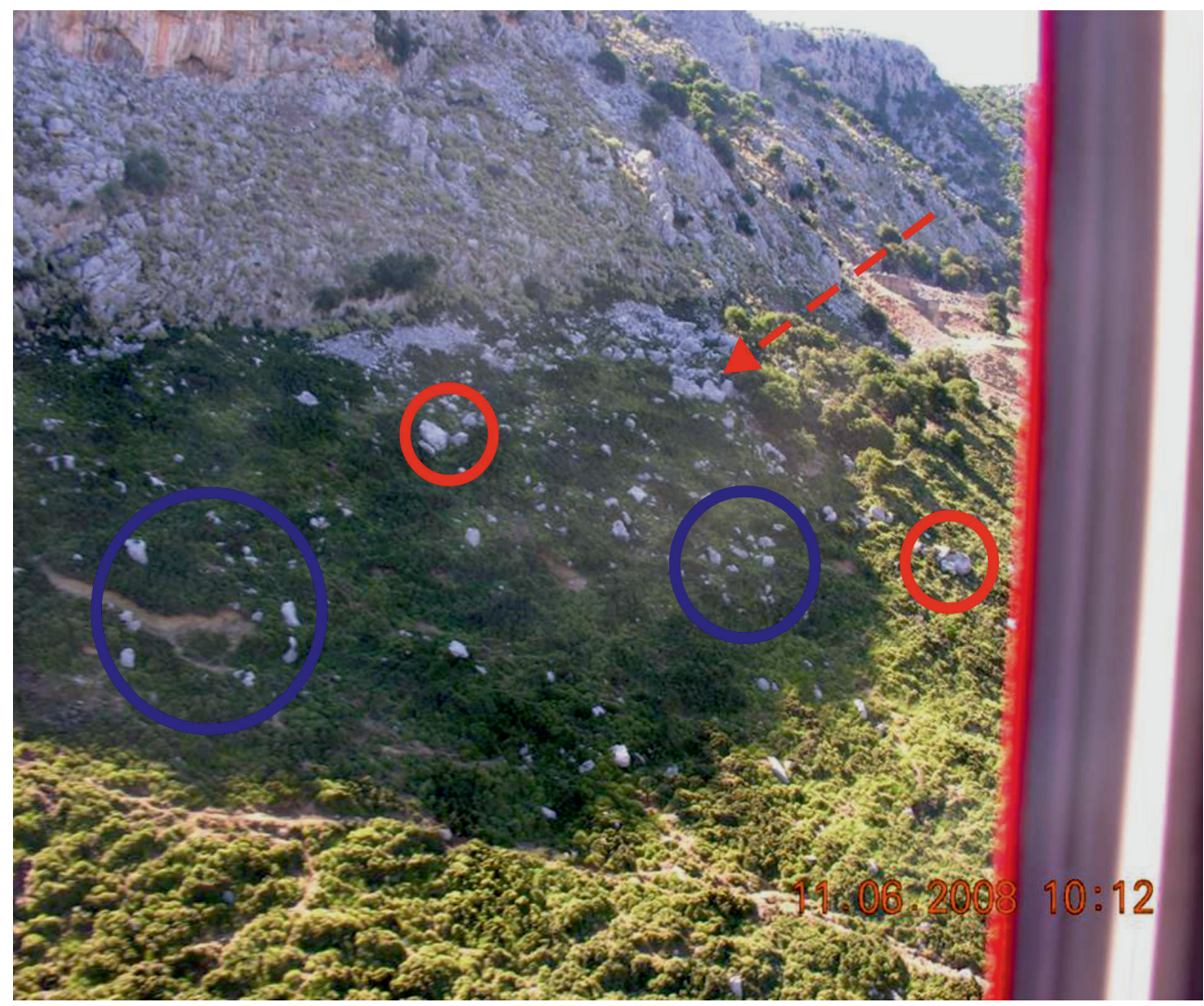

Fig. 6. Helicopter photo that indicates the typical distribution of rock blocks on the western slopes of Skolis Mountain, after the $M w=6.4$ earthquake. Blue and red cycles indicate isolated and clustered boulders.

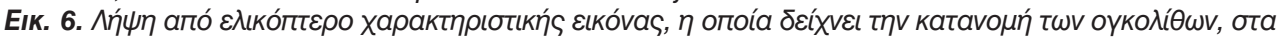

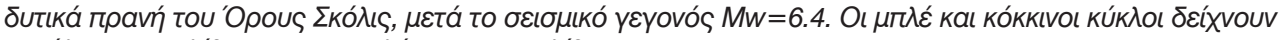

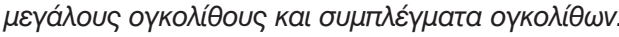

(c) Boulders that bounced on the steep slopes and rolling over the Skolis slope, which means that in this case the trajectories and the rock fall source areas are not obvious (Fig. 8a). Specifically, as regards the type (b), the boulder trajectories start either from the limestone masses or from a talus cone. The area with high concentration of rocks of different sizes threaten the residential area. In order to provide an overview of Skolis Mountain, we divided the slope surface into three zones to evaluate the rock slide and rock fall hazard (table 2.).
The distribution of the isolated rock falls were mapped after the Movri Mountain earthquake. Notwithstanding, along the slopes of Skolis, there are three areas that concentrate a considerable number of boulders (Fig. 7). The most important in terms of hazard area is the concentration of boulders identified nearby and above Santomerion village. Overall the rock fall clustering were recognized along three elongated zones parallel with the strike of the Skolis Mountain (Figs 2, 3,4 and 7). The northern cluster of boulders occupies an area about 1700-mlong (Figs 2 and 7 ). 


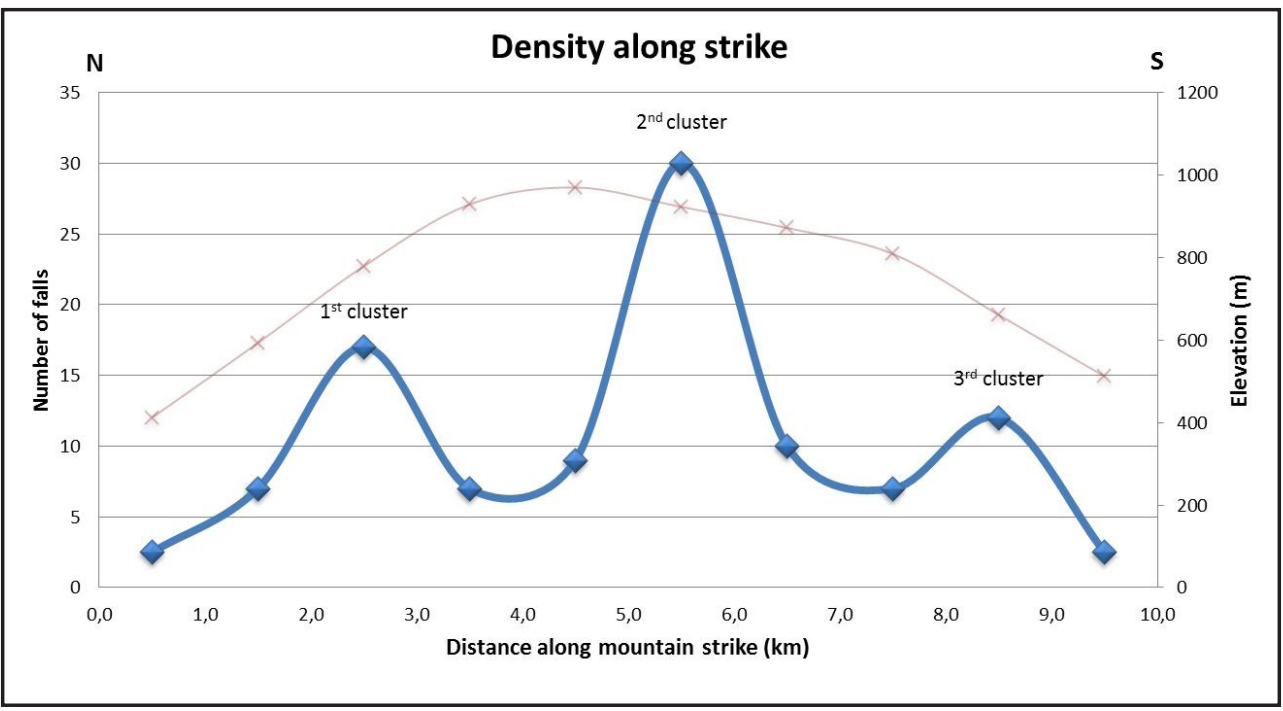

Fig. 7. Correlation chart that illustrates the distribution of boulders according to elevation across the western slopes of Skolis Mountain.

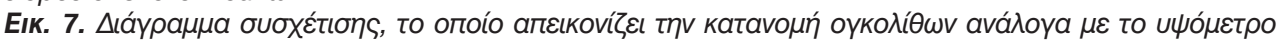

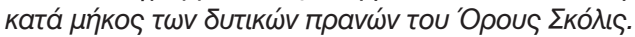

The second cluster of boulders occupies an area with radius of about $1000 \mathrm{~m}$ (Fig. 3 ). The third cluster of rock falls represent a 1500-m-long area to the south of Santomerion village (Figs 2 and 7 ).

\section{Vulnerability}

Out of the three villages located on the mountain bluffs the most affected villages during the Movri mountain earthquakes were Santomerion and Portai villages, located on the western slopes. Santomerion village was by far suffered the most damage due to its proximity to the steepest slopes and high elevation (450 m approximately).

As a result, the largest volume of landslide materials, consisting of rock boulders, hit the village at high speeds.

The rock falls were severe along a 1500 $\mathrm{m}$ long area north and south of the Santomeri village along the Skolis Mountain strike. In this area large blocks of rock were detached from the steep slopes, rolled and toppled down into the village, causing structural damages, and blocking of an extensive network of dirt roads above the village. The large volume of rock falls had a profound economic impact on Santomerion and its residents, causing particular damage in properties. Likewise, the vegetation of the area suffered damage as the boulders uprooted many trees in their wake. However, these trees blocked a significant number of rock falls to reach the village, preventing further damages.

In order to prevent large scale damages and ensure the protection of Santomerion village, a metal wire mesh has been placed to fence the village to future landslides .

\section{Discussion - Conclusions}

Tectonic deformation and relief of Skolis Mountain appears to play a crucial role in the development of threshold conditions for rock slope instability. 

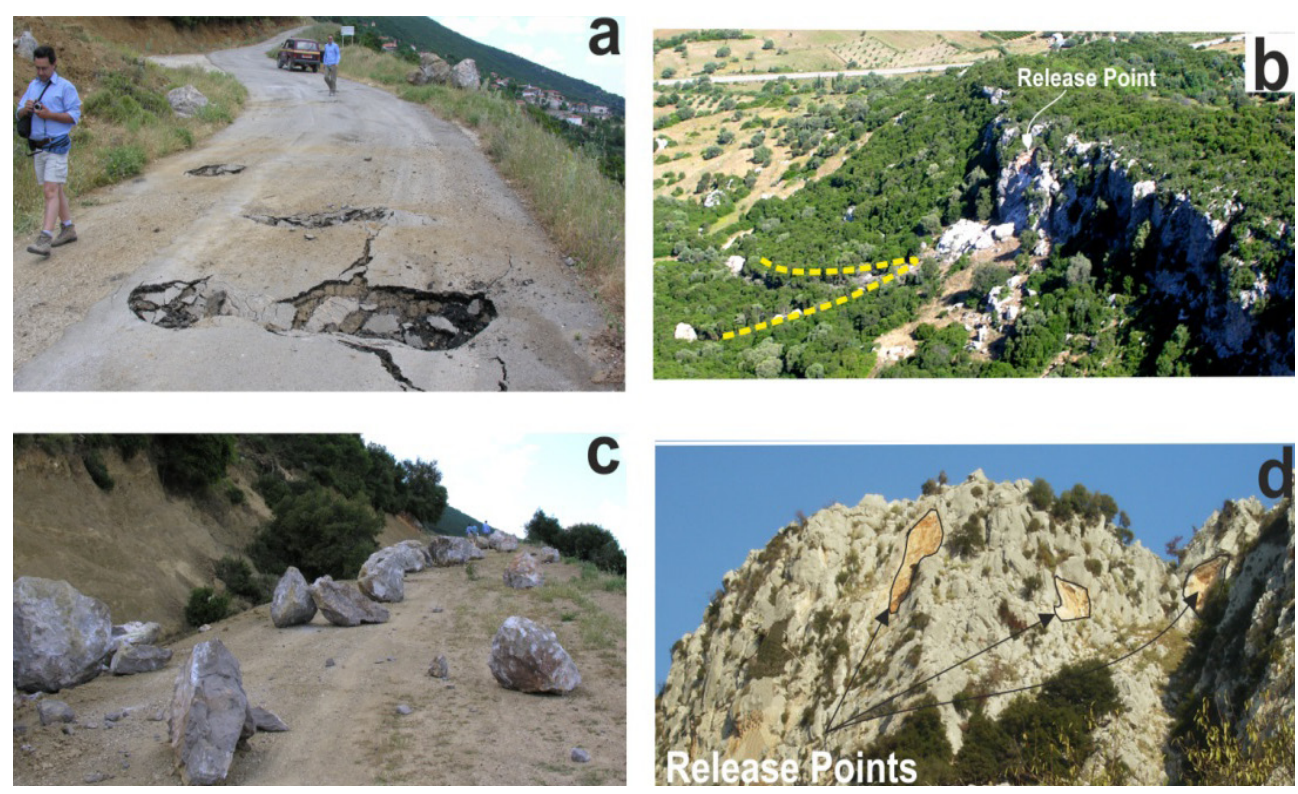

Fig. 8. (a) Bounce marks on asphalt paved and dirty roads around the Santomerion village. Note that the foreground mark is almost two meters long. (b) Helicopter view of a release point along a cross strike normal fault. The yellow dashed lines point out the rock-fall path, which resulted in the destruction of vegetation. (c) Examples of large boulders blocking a dirty road to the north of Santomerion. (d) Rock fall release points, within the steep carbonate rockwalls of the western slopes of Skolis Mountain, above Santomerion village. The release points appeared as reddish outcrops on the cliff. The photos are taken looking east.

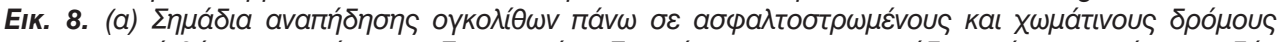

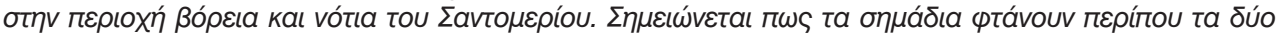

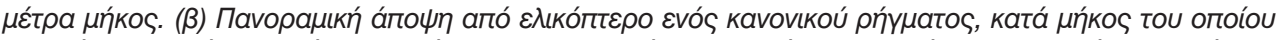

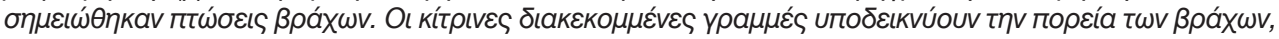

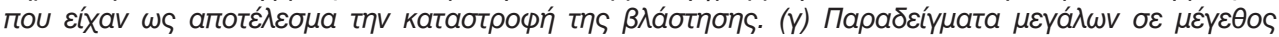

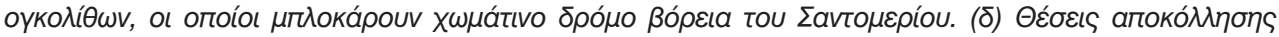

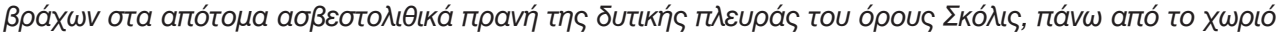

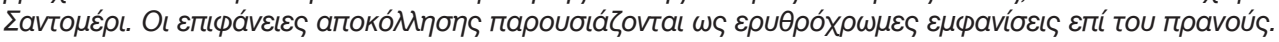

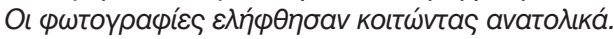

Tectonic stress along with lithology and weathering intensity exert a major control on geometric and strength characteristics of discontinuities and intact rock, with a profound influence on the stability of rock slopes. In particular, the fault and fold related deformation has caused dense fracturing in the carbonate rocks which in combination with the erosion process and the frequent occurrence of seismic shocks, has led to slope instability phenomena, which are manifested as rock fall sites (Litoseliti 2012). Based on remote sensing analy- sis and surface mapping we recognized three zones across the western slope of the Skolis Mountain.

The first zone, which corresponds to the rock fall source area, includes a small number of blocks, characterized by lack of further movement. Rock fall and block toppling have been occurred at high elevation ranging of $450 \mathrm{~m}$ to 630 $\mathrm{m}$, approximately (Fig. 7). The second zone includes the largest number of rock blocks, which bounce on a slope surface or scree slope. The third zone corresponds to the rock fall accumula- 
tion area. At this relatively low altitude area where the mean slope gradient is less than $30^{\circ}$, a significant number of scattered blocks are concentrated. In a wide radius around Santomeri, apart from the materials of 2008 landslide event, many fragments of rocks of past landslides have been identified. During our field mapping, we identified several areas covered by small scale rockavalanches or large blocks resulted by past rockslide events of unknown origin. However, as the seismic history in the area is rather poorly known (see for example Koukouvelas et al., 2010; Zygouri et al., 2013) it is most probable to assume that the meteorological forcing has significant implication to the development of these landslides. This implies that Santomeri village is an area prone to rock fall and block detachment phenomena, which in combination with the seismic activity, are rather extremely dangerous for the public safety (Figs 7 and 8). Another factor that contributes to the local vulnerability is the proximity of Santomeri to the rock fall release points, in the uppermost part of the village. On this slope, the fractured carbonate rockwalls overhang above the village, constituting a major hazard as regards its viability and safety.

Our field- and Google Earth photographs analysis provided us with a map showing that the 2008 Movri Mountain earthquake triggered or reactivated approximately 69 landslides, produced 15 newly formed rock falls and caused 990 isolated rock falls. All these data enable us to draw the following conclusions:

1) The comparison of pre-earthquake with the post-earthquake rock fall distribution indicates that the role of earthquake in causing landslides is more than crucial.

2) The majority of unstable sites are lo- cated on the steeper slopes of the Skolis Mountain, within highly deformed limestones.

3) Most of the 2007 rock falls during the earthquake migrated downward, propagating progressive failure along the pre-existing rock falls. In consequence, the latter were moved further and spread out across the slope surfaces. Commonly the reactivated sliding zones develop a narrow channel, which leads to an accumulation zone, consisted of small blocks of rocks and boulders, most of which are partially broken possibly due to rolling and crashing on the slope.

4) Preexisting rock falls commonly have been wholly reactivated, showing a considerable dimensions expansion of pre-earthquake rock falls. This suggests that earthquake-prone mountain areas are extremely dangerous for the public safety. Hazard is produced by both the increasing of volume of rock falls and expansion of the boulder scattering at least five times the elevation difference between the foothills and crest of the mountain.

\section{Acknowledgements}

The authors would like to thank $\mathrm{H}$. Kranis and an anonymous reviewer for his valuable comments and suggestions that improved the paper, and Prof. A. Zambetaki for her editorial handling.

\section{References}

Agliardi, F., Crosta, G.B., Meloni, F., Valle C., Rivolta, C., 2013. Structurally-controlled instability, damage and slope failure in a porphyry rock mass. Tectonophysics, http://dx.doi. org/10.1016/j.tecto.2013.05.033

Ambraseys, N., 2009. Earthquakes in the Mediterranean and Middle East: a multidisciplinary study of seismic- 
ity up to 1900. Cambridge University Press. xx, pp. 947.

Benker, C.S., Langford, R.P., Pavlis, T.L., 2011. Positional accuracy of the Google Earth terrain model derived from stratigraphic unconformities in the Big Bend region, Texas, USA. Geocarto International, Vol. 26, No. 4, 291-303.

Bull, D.W., King, J., Kong, F., Moutoux, T., Phillips, W.M., 1994. Lichen dating of coseismic landslide hazards in alpine mountains. Geomorphology, 10, 253-264.

Burbank, D.W., Anderson, R.S., 2001. Tectonic Geomorphology. Blackwell, Massachusetts, pp. 274.

Costanzo D., Cappadonia, C., Conoscenti, C., Rotigliano, E., 2012. Exporting a Google EarthTM aided earth-flow susceptibility model: a test in central Sicily. Natural Hazards, 61, 103-114.

Crosta, G., 1998. Regionalization of rainfall threshold: an aid to landslides hazard evaluation. Environmental Geology, 35, 131-145.

Dorren, L.K.A., 2003. A review of rock fall mechanics and modelling approaches. Progress in Physical Geography, 27, 69-87.

Doutsos, T., Koukouvelas, I., Xypolias, P., 2006. A new orogenic model for the External Hellenides. In: Robertson, A.H.F., Mountrakis, D., Brun, J.-P. (Eds.), Tectonic Evolution of the Eastern Mediterranean Regions: Geological Society of London, Special Publications, v. 260, p. 507-520.

Eisbacher, G.H., Clague, J.J., 1984. Destructive mass movements in high mountains: hazard and management. Geological Survey of Canada, pp. 84-16.

Feng, L., Newman, A.V., Farmer, G.T., Psimoulis, P., Stiros, S.C., 2010. En- ergetic rupture, coseismic and postseismic response of the $2008 \mathrm{MW}$ 6.4 Achaia-Elia earthquake in northwestern Peloponnese, Greece: an indicator of an immature transform fault zone. Geophysical Journal International, 183, 103-110.

Gallousi, C., Koukouvelas, I., 2007. Quantifying geomorphic evolution of earthquake-triggered landslides and their relation to active normal faults. An example from the Gulf of Corinth, Greece. Tectonophysics, 440, 85104.

Gallovic, F., Zahradnik, J., Krizova, D., Plicka, V., Sokos, E., Serpetsidaki, A., Tselentis, G.-A., 2009. From earthquake centroid to spatial-temporal rupture evolution: $\mathrm{Mw}$ 6.3 Movri Mountain earthquake, June 8, 2008, Greece. Geophysical Research Letters, 36, L21310, doi:10.1029/2009GL040283.

Ganas, A., Serpelloni, E., Drakatos, G., Kolligri, M., Adamis, I., Tsimi, Ch., and Batsi, E., 2009. The Mw 6.4 SWAchaia (western Greece) earthquake of 8 June 2008: Seismological, field, GPS observations and stress modeling. Journal of Earthquake Engineering, 13, 1101-1124.

Giannopoulos, D., Sokos, E., Konstantinou, K., Lois, A., Tselentis, G.A., 2013. Temporal variation of shearwave splitting parameters before and after the 2008 Movri Mountain earthquake in northwest Peloponnese (Greece). Annals of geophysics, 55 (5), 1027-1038.

Guzzetti, F., Mondini, A.C., Cardinali, M., Fiorucci, F., Santangelo, M., Chang, K.T., 2012. Landslide inventory maps: New tools for an old problem, Earth-Science Reviews, 112, 42-66.

Hatzfeld, D., Pedotti, G., Hatzidimitri- 
ou, P., Makropoulos, K., 1988. The strain pattern in the western Hellenic Arc deduced from a microearthquake survey. Geophysical Journal International, 101, 181-202.

Hatzfeld, D., Kassaras, I., Panagiotopoulos, D., Amorese, D., Makropoulos, K., Karakaisis, G., and Coutant, O., 1995. Microseismicity and Strain Pattern in Northwestern Greece. Tectonics 14, (4) 773-785.

Hutchinson, J. N., 1988. General Report: Morphological and geotechnical parameters of landslides in relation to geology and hydrogeology. Proceedings, Fifth International Symposium on Landslides (Ed: Bonnard, C.), v. 1, p. 3-35. Rotterdam: Balkema

Jabouedoff, M., Labiouse, V., 2011. Technical note: preliminary estimation of rock fall runout zones. Natural Hazards and Earth Systems Science, 11, 819-828.

Jibson, R.W. and Keefer, D.K., 1993. Analysis of the seismic origin of landslides: examples from the New Madrid Seismic Zone. Geological Society of America Bulletin, 105, 521-536.

Kalantzi, F., Doutsou, I., Koukouvelas, I., 2010. Historical landslides in the prefecture of Ioannina- Collection and analysis of data. Bulletin of the Geological Society of Greece, XLIII, 1350-1360.

Kamberis, E., Sotiropoulos, S., Aximniotou, O., Tsaila-Monopoli, S., Ioakim, C., 2000. Late Cenozoic deformation of Gavrovo zone and Ionian zones in NW Peloponnesos (Western Greece). Annali di Geofisica, 43, 905-919.

Kamberis, E., Pavlopoulos, A., TsailaMonopoli, S., Sotiropoulos, S., and loakim, C., 2005. Deepwater sedi- mentation and paleogeography of foreland basins in the NW Peloponnese (Greece). Geologica Carpathica, 56, 503-515.

Karapanos, I., 2009. Hydrogeologicalhydrochemical parameters of the drained Mouria lake (prefecture of Ileia), controlling the rehabilitation and the sustainable management of the wetlands (in Greek). Unpublished PhD Thesis, Department of Geology, University of Patras.

Keefer, D.K., 1984a. Landslides caused by earthquakes. Geological Society of America Bulletin, 95, 406-421.

Keefer, D.K., 1984b. Rock avalanches caused by earthquakes: source characteristics. Science, 223, 12881290.

Kiratzi, A., Louvari, E., 2003. Focal mechanisms of shallow earthquakes in the Aegean Sea and the surrounding lands determined by waveform modeling: a new database. Journal of Geodynamics, 36, 251-274.

Kokkalas, S., Koukouvelas, I., Doutsos, T., 2003. Relationships between tectonic deformation and earthquake induced ground hazards: the case of the August 14th 2003 Lefkada earthquake. First International Workshop on Earthquake Prediction.: Programme with Abstracts ESC, Geodynamics Observatory of Athens, Greece.

Kokkalas, S., Xypolias, P., Koukouvelas, I., Doutsos, T., 2006. Postcollisionalcontractional and extensional deformation in the Aegean region. In: Dilek, Y., Pavlides, S. (Eds.), Postcollisional Tectonics and Magmatism in the Mediterranean Region and Asia: Geological Society of America, Special Paper, 409, pp. 97-123.

Kokkalas S., Xypolias P., Koukouve- 
las I., 2008. Surface ruptures of the Mw 6.3 (June 08 2008). Earthquake event in the Northwest Peloponnese. 31st General Assembly of the European Seismological Commission, Creta Maris Conference Center Hersonissos, Crete, Creece, 7-12 September 2008.

Kokkalas, S., Kamberis, E., Xypolias, P., Sotiropoulos, S., Koukouvelas I., 2013. Coexistence of thin- and thick-skinned tectonics in Zakynthos area (western Greece): Insights from seismic sections and regional seismicity. Tectonophysics, 597$598,73-84$.

Korup, O., 2005a. Distribution of Landslides in Southwest New Zealand. Landslides, 2, 43-51.

Korup, O., 2005b. Large landslides and their effects on sediment flux in South Westland, New Zealand. Earth Surface Processes and Landforms, 30, 305-323.

Koukis, G., Ziourkas, C., 1991. Slope instability phenomena in Greece: a statistical analysis. Bulletin of International Association of Engineering Geologists, 43, 47-60.

Koukis, G., Tsiambaos, G., Sabatakakis, N., 1996. Landslides in Greece: Research, evolution and quantitative analysis. Proceedings 7th International Symposium on Landslides, pp. 1935-1940, Trondhein, Norway, Balkema

Koukouvelas I., 2008. Earthquake-induced landslides and their relationship to active faults over the West Peloponnese. 31st General Assembly of the European Seismological Commission, Creta Maris Conference Center Hersonissos, Crete, Greece 7-12 September, 2008.

Koukouvelas, I.K., Doutsos, T., 1996. Implications of structural segmenta- tion during earthquakes: The 1995 Egion earthquake, Gulf of Corinth, Greece. Journal of Structural Geology, 18, 1381-1388.

Koukouvelas, I., Mpresiakas, A., Sokos, E., and Doutsos, T., 1996. The tectonic setting and earthquake hazards of the 1993 Pyrgos earthquake, Peloponnese, Greece. Journal of the Geological Society London, 153, 39-49.

Koukouvelas, I., Kokkalas, S., Xypolias, P., 2010. Surface deformation during the Mw 6.4 (8 June 2008) Movri Mountain earthquake in the Peloponnese, and its implications for the seismotectonics of western Greece. International Geology Review, 52, 249-268.

Litoseliti, A., 2012. Seismically-induced landslides, before and after the 2008 earthquakes at Skolis Mountain (in Greek). MSc Thesis, Department of Geology, University of Patras.

Marinos, P., Tsiambaos, G., 2002. Earthquake triggering rock falls affecting historic monumentsand a traditional settlement in Skyros island, Greece. Proceedings of the International Symposium Landslide risk mitigation and protection of cultural and natural heritage, pp. 343346, Kyoto, Japan.

Mavroulis, S., Fountoulis, I., Lekkas, E., 2010. Environmental effects caused by the Andravida (08-06-2008, ML $=6.5$, NW Peloponnese, Greece) earthquake. In: A. Williams, G. Pinches, C. Chin, T. McMorran and C. Massey, Editors, Geologically Active: 11th IAEG Congress, Taylor \& Francis Group, Auckland, New Zealand, pp. 451-459.

Mavroulis, S., Fountoulis, I., Skourtsos, E., Lekkas, E., Papanikolaou, I., 2013. Seismic intensity assignments 
for the 2008 Andravida (NW Peloponnese, Greece) strike-slip event ( June $8, M w=6.4$ ) based on the application of the Environmental Seismic Intensity scale (ESI 2007) and the European Macroseismic scale (EMS-98). Geological structure, active tectonics, earthquake environmental effects and damage pattern. Annals of Geophysics, 56, S0681; doi:10.4401/ag-6239.

Molin, P., Pazzaglia, F., Dramis, F., 2004. Geomorphic expression of active tectonics in a rapidly-deforming forearc, Sila Massif, Calabria, Southern Italy. American Journal of Science, 304, 559-589.

Papadopoulos, G.A., and Plessa, A., 2000. Magnitude-distance relations for earthquake induced landslides in Greece. Engineering Geology, 58, 377-386.

Papadopoulos, G.A., Karastathis, V., Kontoes, C., Charalampakis, M.,Fokaefs, A., Papoutsis, I., 2010. Crustal deformation associated with east Mediterranean strike-slip earthquakes: The 8 June 2008 Movri (NW Peloponnese), Greece, earthquake (Mw 6.4). Original Research Article. Tectonophysics, 492, 201-212.

Papathanassiou, G., 2012. Estimating slope failure potential in an earthquake prone area: a case study at Skolis Mountain, NW Peloponnesus, Greece. Bulletin of Engineering Geology and the Environment, 71, 187194.

Pavlides S., Valkaniotis S., Papathanassiou G., Sboras S. and Chatzipetros A., 2008. Surface effects of the strong June 8, 2008, NW Peloponnese earthquake (in Greek). Proceedings of the 3rd Panhellenic Conference of Earthquake Engineering and Engineering Seismology,
Athens, 5-7 November 2008.

Peruccacci, S., Brunetti, M.T., Luciani, S., Vennari, C., Guzzetti, F., 2012. Lithological and seasonal control on rainfall thresholds for the possible initiation of landslides in central Italy. Geomorphology, 139-140, 79-90. Potere David, 2008. Horizontal Positional Accuracy of Google Earth's HighResolution Imagery Archive. Sensors 8, 7973-7981. DOI: 10.3390/ s8127973.

Qiong, H., Wu, W.B.., Xia, T., Yu, Q., Yang, P., Li, Z., Song, Q., 2013. Exploring the Use of Google Earth Imagery and Object-Based Methods in Land Use/Cover Mapping. Remote Sensing, 5, 6026-6042.

Robertson, A.H.F., 2000. Mesozoic-Tertiary tectonic-sedimentary evolution of a south Tethyan oceanic basin and its margins in southern Turkey. Geological Society of London, Special Publication, v. 173, p. 97-138.

Royden, L. H., Papanikolaou, D. J., 2011. Slab segmentation and late Cenozoic disruption of the Hellenic arc. Geochemistry, Geophysics, Geosystems, 12, Q03010, doi:03010.01029/02010GC003280.

Sachpazi, M., Hirn, A., Clément, C., Haslinger, F., Laigle, M., Kissling, E., Charvis, P., Hello, Y., Lépine, J.-C., Sapin, M., and Ansorge, J., 2000. Western Hellenic subduction and Cephalonia Transform. Local earthquakes and plate transport and strain. Tectonophysics, 319, 301319.

Sato, H. P., Harp, E. L., 2009. Interpretation of earthquake-induced landslides triggered by the 12 May 2008 , M 7.9 Wenchuan earthquake in the Beichuan area, Sichuan Province, China using satellite imagery and Google Earth. Landslides, 6, 153- 
159. DOI 10.1007/s10346-009-01476

Serpetsidaki, A., Sokos, E., Tselentis, G.-A., Zahradnik, J., 2009.Seismic sequence near Zakynthos Island, Greece, April 2006.identification of the activated fault plane. Tectonophysics, 480, 23-32.

Schicker, R., Moon, V., 2012. Comparison of bivariate and multivariate statistical approaches in landslide susceptibility mapping at a regional scale. Geomorphology, 161-162, 40-57.

Tibaldi, A., Ferrari, L., Pasquare, G., 1995. Landslides triggered by earthquake and their relations with faults and mountain slope geometry: an example from Ecuador. Geomorphology, 11, 215-226.

Tinsley, J.C., Youd, T.L., Perkins, D.M., and Chen, A.T.F, 1985. Evaluating Liquefaction Potential, in Ziony, J.I., ed., Evaluating earthquake hazards in the Los Angeles Region - An Earth-Science perspective. U.S. Geological Survey Professional Paper, v. 1360 , p. 263-316.

Underhill, J.R., 1989. Late Cenozoic deformation of the Hellenide foreland, western Greece. Geological Society of America Bulletin, 101, 613-634.

Varnes, D.J., 1978. Slope movement types and processes. In Landslides, Analysis and Control. Special Report 176, Transportation Research Board, Washington, pp. 11-33.

Vassilakis, E., Royden, L., Papanikolaou, D., 2011. Kinematic links between subduction along the Hellenic trench and extension in the
Gulf of Corinth, Greece: a multidisciplinary analysis. Earth \& Planetary Science Letters, 303, 108-120.

Vennari, C., Gariano, S. L., Antronico, L., Brunetti, M.T., lovine, G., Peruccacci, S., Terranova, O., Guzzetti, F., 2014. Rainfall thresholds for shallow landslide occurrence in Calabria, southern Italy. Natural Hazards Earth System Sciences, 14, 317-330.

Wilson, R.C. and Keefer, D.K., 1985. Predicting aerial limits of earthquake-induced landsliding. In, J.I. Ziony (ed.), Evaluating earthquake hazards in the Los Angeles region An Earth-Science perspective. U.S. Geological Survey Professional paper, v. 1360, p. 316-345.

Xypolias, P., Doutsos, T., 2000. Kinematics of rock flow in a crustal scale shear zone: implication for the orogenic evolution of the SW Hellenides. Geological Magazine, 137, 81-96.

Yeats, R.S., Sieh, K., Allen C.R., 1997. The geology of earthquakes. Oxford University Press, New York, pp.568 Zêzere, J.L., Ferreira, A.B., Rodrigues, M.L. 1999. The role of conditioning and triggering factors in the occurrence of landslides; a case study in the area north of Lisbon (Portugal). Geomorphology, 30, 133-146.

Zygouri, V., Koukouvelas, I.K., Kokkalas, S., Xypolias, P., Papadopoulos G.A. 2013. The Nisi Fault as a key structure for understanding the active deformation of the NW Peloponnese, Greece. Geomorphology, doi10.1016/j.geomorph.2013.09.001. 